\title{
The Public Life of Charlotte Carmichael Stopes
}

Stephanie Green

This discussion explores some of the ways in which historical narratives can emerge from gaps in the evidence and in our ways of thinking about the past, with reference to the writer, feminist activist and Shakespearean scholar, Charlotte Carmichael Stopes (18411929). A considerable body of manuscript and other archival material relating to the Stopes family is held in public hands. However key items, including Charlotte Stopes's own correspondence with prominent people of her time, have been lost or destroyed. I aim to address the tensions between private and public aspects of Stopes's life as a way of exploring ways in which the absence, as well as the presence, of evidence can influence historical accounts. As I set out to show, with reference to Stopes, historical attention may be drawn to certain kinds of evidence in accordance with dominant cultural narratives, allowing these narratives to be repeatedly rehearsed across generations of scholarship. This process can produce a discursive gap, a failure to recognize marginal or unfashionable contributions to public culture, which in turn produces distortions in the record of the past.

\section{Biographical Note:}

Dr Stephanie Green is a Senior Lecturer in the School of Humanities at Griffith University, where she currently teaches writing and literature. She is a widely published, both as a writer and academic. Her major biographical study The Public Lives of Charlotte and Marie Stopes was published in 2013 by Pickering and Chatto (UK). Her scholarly papers have appeared in journals such as Continuum and TEXT. Her recent short fiction and essays have appeared in Griffith Review and Axon. 
As researchers, historians, biographers and writers, we work with the evidence we gather about our subjects through books, manuscripts, images, ephemera and objects of various kinds; often through repeated visits to a library, museum, archive or personal collection. Even as a by-product of research, these entities of knowledge can be irresistible: a worn fragment of soap kept in a wooden box, the flair and density of hand writing in ink, or a rare bound volume which always opens at a certain yellowed page. The impression of intimacy that the researcher gleans from these materials can create a sense of relationship with the subject; a glimpse of what Jorge Luis Borges described as the 'extravagant joy' of a belief in the possibility of a complete body of knowledge, a whole story, a whole life. ${ }^{1}$ As I will suggest in this paper, however, it may be within the gaps and absences of public and historical record, the incomplete manuscript, missing photograph, lost or censored personal correspondence, or amongst forgotten and unpopular themes and figures, that some of the most fruitful territory for historical writing and research can be found. As Carolyn Steedman observes, the archival historian must, in part, 'read for what is not there: the silence and the absences of the documents always speak to us'. ${ }^{2}$ As this paper will argue, however, the silences of history may be reinforced by distortions and biases in the public record producing multiple and long-lasting erasures.

Questions of bias and missing evidence have a particular significance for the history of women's participation in the public sphere, where misrepresentations of identity and gaps in the historical record serve to foreground social and cultural lines of exclusion. These lines of exclusion reflect socially and culturally dominant value judgments about what should, or should not, be included in memorials of public life. Such judgments, whether institutional or individual, may lead to distortions in accounts of the past, specifically with respect to the roles and contributions of women in public and private life. This paper sets out to address this issue with reference to writer, feminist activist and Shakespearean scholar Charlotte Carmichael Stopes (1841-1929). It will discuss the formative potency of absence in relation to the framing of her public identity, and for how this speaks to the material evidence of her life and work that remains. The public memory surrounding Charlotte Stopes exemplifies how cultural perspectives and 
ways of thinking about the past and its people may be shaped, both by limitations in access to historical evidence and by common assumptions within the representation of women as elders and scholars.

An outstanding school student, but without financial backing after her father's early death in 1854, Charlotte Carmichael began her working life as a tutor and governess, also publishing stories for children. ${ }^{3}$ In her late twenties, she became a pioneer member of the women's higher education movement as the first woman in Scotland to gain a university qualification. ${ }^{4}$ In 1878 she received a Certificate with Honours in Literature, Philosophy and Science, from the University of Edinburgh. ${ }^{5}$ She was well-recognised for her achievement amongst the network of women's emancipationists with whom she worked in Scotland. In her late thirties, she married the brewery architect and paleontologist Henry Stopes and the couple moved to London where she conducted literary discussion groups, joined numerous associations and gained public influence through press coverage of her campaign speeches, her historical writings and her Athenaeum essays on Shakespearean matters. Her research brought new aspects of English Renaissance theatre history to light and helped to broaden knowledge and understanding of Shakespeare and his contemporaries.

Charlotte Carmichael Stopes's contribution to the advancement of women's emancipation in Britain has been acknowledged by contemporary historians, ${ }^{6}$ but for much of the twentieth century her work was little known or understood. A regular inhabitant of the British Museum Reading Room in later life, obituaries portrayed her as a Shakespearean dilettante: a loquacious old-fashioned female of tedious cast who had failed to make a significant contribution to Shakespearean scholarship. ${ }^{7}$ This posthumous persona was arguably the legacy of a gendered academic stance, encapsulated in 1970 by Samuel Schoenbaum's epithet for her as a 'Hampstead matron' with a 'rage for discovery. ${ }^{8}$ In subsequent decades, she has been best known as the mother of Marie Stopes (1880-1958), whose reputation as a controversial sex educationalist and birth control advocate held greater contemporary appeal for cultural historians and sociologists than the political, cultural and educational reform work of her stoical Scottish mother. In some accounts, moreover, Charlotte Stopes is portrayed as sharply disapproving, even 
sexually repressed. ${ }^{9}$ These accounts do not take in the full circumstances and achievements of her career.

Two key instances of missing evidence in the case of Charlotte Stopes provide a focus for this discussion. The first significant gap in the archival evidence relates to personal correspondence received by Charlotte from her husband, Henry Stopes. As discussed in biographical studies of her daughter, ${ }^{10}$ key sections of the handwritten letters that deal with emotional issues in their early relationship have been cut out, leaving partial but suggestive passages behind. How these epistolary excisions should be interpreted is, to some extent, open to question. That these letters were kept by Marie Stopes indicates her own sense of their importance for understanding her parents' marriage. This evidentiary gap offers a reminder, however, that a part of the story can be found elsewhere; in mislaid evidence, deliberate acts of erasure, or biases in recognition and interpretation.

The second instance of missing evidence relates to the correspondence Charlotte Stopes received from Oscar and Constance Wilde between 1889 and 1890, concerning her periodical submissions for The Woman's World and the Rational Dress Society Gazette. ${ }^{11}$ A minor public figure when women were just beginning to gain access to universities and the professions, this Scottish author pursued publication opportunities in these and other journals with considerable energy. Her letters from the Wildes were retained by her daughter, and later collected by the British Library, but her own letters from this exchange were not preserved. These two instances of erasure, one deliberate, the other inadvertent, cannot be considered in isolation from Stopes's public identity as a scholarly writer and as an advocate for women's rights. They will first be considered here in relation to the context of her framing as a rational dress and women's rights activist in the British press during the late 1880s. I will then go on to discuss the implications of the censored letters for understanding how Stopes has been positioned as an outlandish identity.

The cultural conditions in which middle class European women of the mid-late nineteenth century achieved social inclusion were dynamic and evolving. Lucy Delap 
observes with reference to Karen Offen that improved rates in female literacy and participation in urban workforces, new developments in European nationhood, and a divergence between feminism and socialism, were among the factors that contributed to the movement to claim full citizenship for British women. ${ }^{12}$ As they campaigned for equal independence, opportunities for women's public cultural engagement were burgeoning during the second half of the century. ${ }^{13}$ That women also faced significant obstacles in Victorian Britain to their formal participation in professional and academic fields has been well-demonstrated by a substantial body of feminist scholarship. ${ }^{14}$ This work shows the extent to which the university establishment resisted the development of higher education for women in the late nineteenth century. ${ }^{15}$ At the same time, advocates of women's education, including teachers, writers and journalists, employed a range of covert and overt strategies, including anonymous and pseudonymous authorship, collaborative teaching and publishing enterprises to combat the establishment views. ${ }^{16}$ Although universities were largely inaccessible to women scholars, the many literary groups and associations which flourished in the latter half of the nineteenth century created opportunities for women to pursue independent writing, editing and research. ${ }^{17}$ Many Victorian women writers thus successfully negotiated the discipline of textual production, the quotidian challenges of domesticity, and the competitive demands of the publishing marketplace to become recognized authors and public commentators. ${ }^{18}$

As a scholar, writer, activist, wife and mother, Stopes encapsulates this multifaceted and performative engagement in mid-late Victorian private and public life. She was consistent in pursuing her intellectual ambitions and seeking to overcome the institutional obstacles that she and other women faced, but her motivations were also practical ones. During the late 1880s and early 1890s, her husband's business enterprises were failing. In 1889, Henry Stopes spent a large sum on an unsuccessful attempt to win the seat of Southwark West in the London County Council election. He was fined for excessive expenditure, and forced to pay legal costs to another unsuccessful candidate who objected to his plea to be forgiven the fine. ${ }^{19}$ Three years later, he was forced into bankruptcy. ${ }^{20}$ Nowhere in her published writings, nor in her unpublished autobiography, does Stopes refer directly to the shameful bankruptcy, but her later letters to her daughter 
provide evidence of her financial desperation and the lasting anxiety that it produced. ${ }^{21}$ Susan Nelson points to the importance of financial security for bourgeois families such as the Stopes, suggesting that it was not uncommon for husbands to spend relatively little time at home. ${ }^{22}$ Wives were expected to organize the household around the husband's needs, while his responsibility was to provide for the family. However, the extent to which Victorian couples followed convention varied considerably. As Nelson points out with reference to Mary Singleton's 1892 critique of the idealization of the marriage contract, for many women marriage was a form of entrapment. ${ }^{23}$ Neither Charlotte nor Henry strove to meet assumed norms, however. While their correspondence suggests that a lasting comradeship developed between them, each found domestic life constraining and sought to pursue their interests on their own terms, sometimes spending lengthy periods apart. The autonomy that characterized their marriage was perhaps not as unusual as post-Victorian narratives of gendered middle class domesticity may seem to suggest. As Eleanor Gordon and Gwyneth Nair point out, the ideal of the bourgeois nuclear family did not altogether reflect the Victorian reality. ${ }^{24}$

Their shared interests and beliefs at first augured well for a future together. Although she was a decade older than her husband, Stopes's adventures as an advocate for women's higher education in Scotland, and later for the Rational Dress movement in London, reflect her considerable energy and flair as a figure of social and political change, while Henry's letters indicate that she had strong appeal for him as a companion and lover. Yet, from early in the marriage, the intimacy between them seems to have been strained. 'Brought up in the clamp of Victorian prudery', as Rose puts it, ${ }^{25}$ Marie Stopes believed that her mother knew nothing about sex before her marriage. Several of Marie's biographers have described Charlotte's response to Henry as sexless and distant. Ruth Hall suggests, further, that Charlotte was too ignorant and uncomfortable about sex to advise her daughter about her sexuality and that this motivated Marie's ideas about the value of sex education. ${ }^{26}$ This argument had topicality and appeal for developing the narrative of Marie's career shift from scientist to sex education campaigner, following the annulment of her first marriage. This lively application of the repressive hypothesis, however, was to frame Charlotte Stopes in gendered terms as a fusty spinster who had no 
business marrying a handsome young entrepreneur. Arguably, at least to some extent, this analysis overlooks the importance of her contribution to social change for women. More specifically, it ignores the extent to which the representation of women as marginal shaped public accounts of women and literary history in Britain.

The impression conveyed by Marie Stopes's biographers that her mother found intimacy distasteful is made partly on the basis of deflected interpretation, from letters she received from Henry early in their marriage while he was away at a British Association meeting. She was then living with her mother in Edinburgh, soon due to give birth to their first child. Without any prospect of the settled home he had promised her, she was worried about their future. On the whole, Henry's letters are affectionate and full of his plans for their future. He was characteristically juggling several projects at once, often irritated by small failures. He seems to have argued with Charlotte prior to his departure: one of his letters refers to the 'trouble' between them. ${ }^{27}$ As with several of their letters from this period, a section fold has been cut out: presumably to keep the 'trouble' private. ${ }^{28}$ Charlotte kept Henry's letters from this early period in their marriage until the end of her life, but there is no evidence that he kept her replies. With only his side of the correspondence extant, it is difficult to determine whether sex-rather than money or childbirth, for instance-was the matter. This letter, cited in part by Hall and Rose as the first sign of sexual trouble, when read in its entirety indicates that several issues were at stake. ${ }^{29}$

\section{My Darling,}

Thank you for your letter. It is very good of you. Perhaps my last lets you into the reason why I let such trifles irritate me more than in others' opinion they might. But I can't help it.

Tell me what is the other danger that may make you care less for me than you even now do? You speak of want of frankness and something else. Say what it is. 
Things seem generally to come to me in waves. The other day and till now I was all gloom. Now I am more than glad. My papers in Egypt and Palestine were a great success ... Professor Boyd Dawkins' eyes fairly gleamed. ${ }^{30}$

Her answer must have given him short shrift. She had evidently asked him to be more open with her. New to the burdens of marriage, he wrote again from Swansea refusing to reveal, 'those things which I much question if you have a right to know and which I certainly think you have the advantage of not being told.${ }^{31}$ These letters were written at a time of high emotion in Stopes's life, when she was apart from her husband, worried about the uncertainty of her future and about to give birth to her first child at the age of forty. Once they were settled with their baby in Norwood, she became pregnant again towards the end of 1883. Throughout the subsequent years of their marriage, Henry's various projects would take him away from the family for notable periods, ${ }^{32}$ while Charlotte was preoccupied with her research interests. If early expectations were disappointed on both sides, their respect and admiration for each remained strong and mutual, and they shared moments of intimacy and affection throughout their marriage. ${ }^{33}$

As this discussion suggests, however, the extant archival materials do not provide a full picture of Charlotte's position, either as a private or as a public figure. The absence of her epistolary voice in this exchange between husband and wife after their marriage allows no counterbalance or corroborative evidence for the interpretations that have been offered. The tropes of anti-feminine identity with which Charlotte Stopes has been identified-frigidity, anti-masculinist feminism, complaint, obsession with archaic trivia-have been rehearsed in other twentieth-century accounts. ${ }^{34}$ While the interpretations arising from these gaps in the evidence point to the rehearsal of gendered hierarchies of value in terms of domesticity and authorship, these interpretations do not encompass the scope of her attitudes or achievements. Sarah Richardson observes with reference to Kathryn Gleadle, that women were actively engaged in public life during the nineteenth century, negotiating the available spaces of social and political discourse as citizens on the borders of inclusion and exclusion. ${ }^{35}$ Stopes was not altogether unusual in seeking to identify herself as a citizen, as well as a wife. That her twentieth-century 
reputation identified her, to some extent, in terms of sexual and domestic failure, ${ }^{36}$ is directly at odds with the terms in which she identified herself, as a British citizen with long held rights to educational, political and cultural engagement. Her multifaceted status, negotiating the gendered 'borderline', as Kathryn Gleadle identifies it, between intellectual recognition and obscurity. ${ }^{37}$

Towards the end of the 1880s, Henry's business affairs were unsettled. Writing was almost the only source of income available to Charlotte, and by the end of the 1880s she was active in her attempts to publish. She had begun to produce light hearted articles about drinking habits in Shakespearean times for her husband's 'in-house' magazine Wine, Spirit and Beer. ${ }^{38}$ Her research for this work was the basis for her book, The Bacon-Shakespeare Question. ${ }^{39}$ The book brought her a small reputation, but it was her sudden fame around the nation as the leader of the widely reported Rational Dress coup at the 1889 meeting of the British Association for the Advancement of Science that piqued Oscar Wilde's interest as literary editor of The Women's World.

The confluence of her longstanding membership of the British Association and her more recent involvement in the Rational Dress movement provided Charlotte Stopes with the opportunity to speak publicly about women's dress as a physiological science issue. With her Edinburgh friends, she had previously tried to recruit the British Association to promote women's causes, setting up meetings to discuss related issues such as female suffrage and the higher education of women. ${ }^{40}$ Her 1889 performance was the third and most successful of these attempts. Prior to the Newcastle meeting, she had prepared a paper on the subject, from which she spoke alongside other panelists. Her flair and daring attracted attention and the speech was reported with astonishing breadth, alacrity, and sometimes animosity, in the British press. For the newspapers of the day, Stopes's dress reform lecture offered a sensational topic, with opportunities for subtle and not so subtle allusions to the feminine form. Well over a hundred British and foreign newspapers wrote up the novel event. Although its relevance for science may have seemed questionable to the British Association establishment - her reformist criticism of the strictures of fashion was popularly derided - the topic undoubtedly had livelier appeal for the press than the 
annual round of geological, botanical and astronomical presentations. It also carried media prominence for the dress reform movement, which would ultimately work both for and against its interests.

Reports varied in the extent to which they approved or disapproved Charlotte Stopes's public action. The Aberdeen Journal was among the most tolerant of what was described as:

one more illustration of the truth how helpless is the wisdom of man when pitted against women's wit.... The ladies were not to be gainsaid. They constituted a physiological section, secured a chairman, and had the subject in which they have so deep and personal an interest fully debated in presence of one of the largest audiences that have listened to any of the sectional papers this year. And who shall say that the subject was not one deserving of all the attention it excited? Certainly, the lecturer, Mrs Stopes, of London, handled it in a thoroughly fresh and practical fashion. ${ }^{41}$

A nice demonstration of the mechanism of gendered erasure at work, the tropes of bemused approbation in this article are exercised by way of patronising flourishes. The tone was more sharply dismissive in other reports which relegated the female mind to the fleeting whims of fashion commerce, and in the case of Punch, was blatantly and satirically dismissive. ${ }^{42}$ Another such report feared that:

all the condemnation of Mrs. Stopes and the august body of savans she addressed will not diminish the feminine craze ... Venus the impersonation of womanly beauty, may have worn no corsets, but that lovely Greek lady did not live in an age when one might as well be out of the world as out of the fashion. ${ }^{43}$

Stopes was by then a well-known name among the New Women who set forth to occupy the public cultural sphere of late nineteenth-century Britain. Yet, hitched to the seemingly 
paradoxical irrationality of rational dress reformism, her public persona was stained with the flavour of eccentric absurdity.

Stopes now had an opportunity to capitalize on her sudden fame, however. Before her appearance in Newcastle, she had submitted several articles to the editorial desk of the Woman's World without success. Oscar Wilde had taken over the editorship of the literary pages of the magazine in 1887, and announced his aim to publish quality, authorattributed articles by women. ${ }^{44}$ With her name appearing in almost every newspaper around the country, Wilde wrote to her, inviting her to revise her 'women's dress' paper for publication as an article. ${ }^{45}$ She seized this as her entry into the pages of mainstream advocacy, both for the women's movement and for her own writing career. The articles she offered, both published and unpublished, show Stopes at work as a freelance writer of articles she thought might interest an educated, middle-class, female reader. She was not entirely at one with her task. A number of letters sent to Stopes from the editorial office of the Woman's World in response to her submissions were saved and are held with the British Library's Stopes collection: the legacy of her daughter's estate. The surviving letters are interesting for their variance of tone, ranging from stiff courtesy to harried irritation in the face of her persistence. She seems to have re-submitted articles to the editorial office which had been rejected, with little correction. When articles were accepted on the proviso that revisions would be made, it appears that she often argued against the changes proposed, at some length. ${ }^{46}$

This impression reflects only one side of the communication. Without the corresponding letters sent by Stopes herself to the Woman's World, it is impossible to determine if the editorial tone is commensurate, nor to identify the imperatives of discourse which they reflect; particularly with regard to subjects considered suitable for a mainstream female reader's market. It is clear that she wrote prolifically and that the array of her proposed topics was very broad. Some of these emerged from her developing interests as a Renaissance literary historian and were considered too highbrow for Cassell \& $\mathrm{Co}^{4}{ }^{47}$ Some of her suggestions reflected an attempt to position herself as a literary 
essayist, but were misdirected. She would have much greater success a few years later, as the Shakespeare expert for The Athenaeum. ${ }^{48}$

Charlotte Stopes's attempts to overcome editorial gate-keeping at the Woman's World were ultimately successful, and many of the articles she submitted were eventually published by dint of her persistence. Although it was Wilde who had first invited her to contribute to the magazine, rather more of her work was published once he had resigned from the position of literary editor. However, the missing correspondence tends to reinforce the presumption made by a number of scholars that she was, during this period, little more than a 'battered hack', struggling to make her way. ${ }^{49}$ Some of her concerns have seemed odd or trivial to later researchers, but this may well be to overlook the potency of the social and cultural context in which she wrote, and to forget the discursive biases of historical perspective. Topics that were at first considered by Wilde to be too narrow for mainstream publication were later accepted by the in-house editor as of relevance for readers, in a period when social and public roles for women were changing. These included articles about women leaders in different times and places, food preservation, as well as dress reform. Some of her subjects have been regarded as idiosyncratic, in particular her disquisition upon the evils of refrigeration, ${ }^{50}$ although the mass production of home refrigerators did not take place in Europe until well into the following century and that, along with sanitation reforms and beer adulteration, food spoilage was a significant issue which had profound impacts on population health and longevity. ${ }^{51}$ The adoption of a variety of such subjects in her articles for the Woman's World reflects an attempt to adopt the professional expediency of a freelance writer. Undoubtedly this has contributed to the cultural construction of Stopes as a minor woman writer of obscure preoccupations. Her later efforts as a scholar seem to have been considered in something of this same light, as products of obsession with causes. Her literary books and articles were widely-published during the 1890s and 1910s, but, regarded as a figure of blue-stocking fervor, she never garnered the recognition she sought. That writing was her main source of income, from the time of her husband's financial losses, seems to have further positioned her as a 'battered' writer of odd subjects. ${ }^{52}$ 
Without her own letters to the editorial desk of the Woman's World, Stopes's capacity for persuasiveness, her understanding of her audience and her relevance as a public commentator on matters of contemporary concern to women readers are easily overlooked. While some publishers retained the letters of major literary authors, Chapman and Hall, John Murray and Victor Gollancz among them, the production and author files of small or short lived publishing enterprises, particularly those relating to the work of minor authors, did not necessarily survive. That Stopes's letters were lost may also be indicative of in-house values and priorities of the time. Although Woman's World had a star editor for its literary pages in Oscar Wilde, the magazine held an uncertain status and only survived until the end of 1890, perhaps overshadowed by the company's flagship publications such as Cassell's Family Magazine. Once a pioneer of serial publication, ${ }^{53}$ as Sue Thomas argues, Cassell's was slow in adapting to changing community standards. ${ }^{54}$ The company's managers were known to debate with Wilde about the intellectual and social reform content of The Woman's World. As the publisher's editor, Arthur Fish observed:

Some of the articles on women's work and their position in politics were far in advance of the thought of the day and Sir Wemyss Reid, then General Manager of Cassell's, or John Williams the Chief Editor, would call in at our room and discuss them with Oscar Wilde, who would always express his entire sympathy with the views of the writers and reveal a liberality of thought with regard to the political aspirations of women that was undoubtedly sincere. ${ }^{55}$

By the beginning of 1890 , however, Wilde had lost interest in writing and speaking about the importance of women's costume. In practical terms, as Petra Dierke-Thrun remarks, he was, 'hard pressed to live up to the tight publishing schedule and a lifestyle of regular office work' ${ }^{56}$ The magazine was quickly forgotten and Stopes's letters to Wilde and Fish were evidently discarded. She would have to wait almost another twenty years for formal recognition of her literary worth. ${ }^{57}$ 
In 1892, Henry was forced to sell their graceful family home in Norwood due to bankruptcy. ${ }^{58}$ The children were sent away to school in Edinburgh for two years. Charlotte rented a terrace house near the British Museum, while Henry based himself at his house in Swanscombe. He continued with his business activities until his death in 1902, but never regained solvency. These events galvanised her on several fronts; as a mother, activist, historian, and as a scholar with ambition to make a name in the world of Shakespeare studies. In 1897 she was among the first to join a newly established private members club for women interested in educational, social and philanthropic work: known as the Women's Institute (1897-1928). ${ }^{59}$ For the activist women of Charlotte's generation, the Institute was both an information bureau and a cultural venue. It offered a library, a schedule of public lectures and events, secretarial services, and meeting rooms. There were other clubs for women recently established, including the Somerville Club (1878), the University Women's Club (1886) and the Pioneer (1892). Reflecting the advances women had made during the late nineteenth century, clubs like the Women's Institute were evidence that women had become a consolidated force for social change in Britain. The Institute had close links with a variety of women's organizations. Founded by Nora Wynford Philipps in 1897 at 15 Grosvenor Crescent, its distinguished members included figures, such as Dorothea Beale, Florence Dixie, Helen Blackburn, Isabel Somerset, Millicent Fawcett, and Phillipa Strachey. ${ }^{60}$ Charlotte was an active member, using the auspices of the club to speak on behalf of social and political reform, on suffrage platforms and in print. ${ }^{61}$ From this point on, the traces of her public identity are evident.

During this period, Stopes published her study of women as citizens and leaders in British history, British Freewomen (1890) and produced articles for various progressive magazines and journals, including the Humanitarian, the Woman's Signal, Englishwomen's Review and Shafts. ${ }^{62}$ In this same period, she published an extensive series of articles on Shakespearean themes for The Athenaeum, and became recognized as an authority on the English Renaissance. She engaged openly in controversies with other scholars through public lectures and academic journals. Without a full degree 
qualification or a post in a university, however, her career was necessarily undertaken at the academic margins and, although she did receive acknowledgements of her intellectual contribution to her field, ${ }^{63}$ she remained highly conscious of the limitations that the exclusion of women from universities before the 1890 s had placed on her career. ${ }^{64}$

At the end of her life, theatre director William Poel (1852-1934) reflected sympathetically that although no one had done 'more valuable work for Shakespeare students than Mrs C.C. Stopes' ${ }^{65}$ she never received her due as a Shakespearean scholar: 'that was because she was a woman I fear!' ${ }^{66}$ H.R. Woudhuysen observes that her approach to Shakespearean research was idiosyncratic, ${ }^{67}$ while her critics complained that her published work was wrought with sometimes superfluous detail and conversational asides. Her research has been useful to subsequent scholars for her detailed compilations of archival evidence, although there have been few scholars patient enough to examine her literary research as a body of work. This may be attributed, in part, to the emergence of new ways of thinking about the literature and culture of the past. It also reflects the concessionary tone in which her work had previously been acknowledged, characterising her 'minute researches' as the faded voice of late Victorian amateurism. ${ }^{68}$

Contemporary scholarship has re-addressed Charlotte Stopes's legacy for women's history and her contribution to Shakespeare studies. ${ }^{69}$ The patina of a reputation for esoteric minutiae is nevertheless difficult to shift. Frederick Boas was neither the first nor the last twentieth-century male academic to refer to Stopes in these terms. ${ }^{70}$ Yet, arguably, it was her coherent, evidence-based advocacy of political and intellectual emancipation for women that encapsulated her lasting contribution to British women's history. ${ }^{71}$ Her representation as a freelance writer of $a d$ hoc articles, and as a selfabsorbed and sexually repressed wife, has muffled her far more dashing public persona as an energetic campaigner for radical changes in women's lives. A young woman with passionate dreams and desires and a powerful intellectual curiosity, this undaunted feminist scholar felt that she was a negated presence in the public culture of her own time. In her historical writing, she identified Victorian attitudes towards women as a repressive aberration, arguing that 'women's enfranchisement promised a return to the 
true basis of British democracy' ${ }^{72}$ Her contribution to female emancipation was perhaps obscured by her daughter's prominent and controversial career. To some extent, Marie Stopes set out to define herself against her mother, in scholarly and personal terms. Arguably, the scandal of her reputation as an advocate of sex education and birth control positioned her in the early twentieth-century public eye as the more excitingly radical of the two women. ${ }^{73}$ In many ways, however, Charlotte Stopes was the greater pioneer as a progressive reformer: determined to prove by her own efforts that a woman could gain a university education and succeed within the sphere of public letters, knowledge and ideas. She exemplifies the women of her time who navigated the terrain of gendered discourse, embracing multiple identities as a writer, scholar, wife, mother and activist, and confronting the challenges and the opportunities that late nineteenth-century women faced in gaining recognition for their work.

\section{Notes}

1 Jorge Luis Borges (1962) 'The Library of Babel', Ficciones (New York: Grove Press), p. 83.

2 Carolyn Steedman (2001) 'Something She Called a Fever: Michelet, Derrida, and Dust', American Historical Review, 106:4, pp.

1159-1180, on p. 1165 .

3 Brown, S., Clements, P. and Grundy, I., (Eds) (2006) 'Charlotte Stopes' Orlando: Women's Writing in the British Isles from the

Beginnings to the Present (Cambridge: Cambridge University Press Online) at http://orlando.cambridge.org/

4 Blain,V., Clements, P., Grundy, I. (1990) The Feminist Companion to Literature in English (London: Batsford), p. 1034.

5 Certificate with Honours, University of Edinburgh, April 1878, Stopes-Roe Private Archive, Birmingham (hereafter S-R Archive).

The Certificate in Arts was available to women at Edinburgh University from 1874. Charlotte also received a Diploma from the Edinburgh Ladies Educational Association in April 1879.

6 Pedersen, J . (1996) 'The Historiography of the Women's Movement in Victorian and Edwardian England: Varieties of Contemporary Liberal Feminist Interpretation', The European Legacy: Toward New Paradigms, Special Issue: Fourth International Conference of the International Society for the Study of European Ideas, 1:3, pp. 1052-1057: Mayhall, L. E. N. (2000) 'Defining Militancy: Radical Protest, the Constitutional Idiom, and Women's Suffrage in Britain, 1908-1909', Journal of British Studies, 39:3, pp. 340-371: McLuskie, K. (2013) 'Remembering Charlotte Stopes' in G. McMullan, L. Cowan Orline and V. Mason (Eds) Women Making Shakespeare: Text, Reception and Performance (London and New York: Bloomsbury Arden Shakespeare). 
7 Frederic Boas, 'Charlotte Carmichael Stopes, some aspects of her life and work', Essays by Divers Hands: Transactions of the Royal Society of Literature 10 (London: Royal Society of Literature, 1931).

8 Schoenbaum, S. (1991) Shakespeare's Lives (Oxford: Oxford University Press), p. 460. First published by Clarendon Press in 1970. 9 Hall, R. (1977) Passionate Crusader, the life of Marie Stopes (London: Harcourt, Brace, Jovanovich), pp. 15-27. Blain, et. al. p 1034.

10 Hall, 1977, pp. 18-21.

11 Stopes Papers Volume VIII, Manuscript Collection. British Library, London, Add. 58454, ff. 2-52 (Hereafter the British Library Manuscript Collection will be referred to as BL MS).

12 Lucy Delap (2011) 'The Woman Question and the Origins of Feminism', in G. S. Jones and G. Claeys (Eds) The Cambridge History of Nineteenth Century Political Thought (Cambridge: Cambridge University Press), pp. 319-345, on p. 326.

13 Megan Smitley (2010) The Feminine Public Sphere: Middle Class Women and Civic Life in Scotland, 1870-1914 (Manchester: Manchester University Press); Eileen Janes Yeo (1998) 'Some Paradoxes of Empowerment', in E. Yeo (Eds) Radical Femininity: Women's Self-Representation in the Public Sphere (Manchester University Press), pp. 1-24; Jill Ehnenn (2008) Women's Literary Collaboration, Queerness and late-Victorian Literary Culture (Aldershot: Ashgate).

14 June Purvis (Ed.) (1997) Women's History in Britain, An Introduction (New York: Routledge \& UCLA Press).

15 Jane McDermid (1995) 'Women and Education’, in J. Purvis (Ed.) 1997, pp.107-130, on p. 95.

16 Hilary Fraser, Judith Johnston, \& Stephanie Green (2003) Gender and the Victorian Periodical (Cambridge: Cambridge University Press), p. 27.

17 Georgianna Zeigler (2012) 'Women and Shakespeare', in G. Marshall (Ed.) Shakespeare in the Nineteenth Century (Cambridge: University of Cambridge Press), p. 215.

18 Ehnenn, 2008, p. 26. See also Bradley Deane (2003) The Making of the Victorian Novelist: Anxieties of Authorship in the Mass Market (London \& New York: Routledge) and Beth Palmer (2011) Women's Authorship and Editorship in Victorian Culture (Oxford: Oxford University Press).

19 Society and Personal Notes, Essex Standard, 9 March 1889, p. 6.

20 The Downward Path, Reynolds Newspaper, 31 January 1892, p. 6.

21 Charlotte Stopes to Marie Stopes, 17 June 1904, BL MS, Add. 58449, f. 180.

15 Susan Nelson (2007) Family Ties in Victorian Britain (Westport: Praeger/Greenwood), pp. 30-33.

16 Nelson, Family Ties, p, 37.

24 Eleanor Gordon \& Gwyneth Nair (2003) Public Lives: Women, Family and Society in Victorian Britain (Great Britain: Yale University Press), pp. 39-45.

25 Rose, Marie Stopes and the Sexual Revolution, p. 9.

26 Hall, Passionate Crusader, pp. 19-21.

27 Henry Stopes \& Charlotte Stopes (1878-1892) Stopes Correspondence, Wenban-Smith Archive (hereafter W-S Archive), Southhampton.

28 Henry Stopes to Charlotte Stopes, 1 September 1880, W-S Archive.

29 Rose, J. (1993) Marie Stopes Marie Stopes and the Sexual Revolution (London: Faber and Faber); Hall, 1977, p. 5; Hall,

Passionate Crusader, p. 20.

30 Henry Stopes to Charlotte Stopes, 27 August 1880, W-S Archive.

31 Henry Stopes to Charlotte Stopes, 1 September 1880, W-S Archive.

32 Keith Briant (1962) Passionate Paradox: The Life of Marie Stopes (London: Norton), p. 20.

33 Charlotte travelled to Portsmouth to see Henry off on his journeys to North America. Sometimes they met in picturesque country villages for lunch or to browse through old bookshops, and attended conferences together.

34 Schoenbaum, 1991, pp. 460-461; William Garrett (2007) Marie Stopes: Feminist Eroticist, Eugenicist (San Francisco: Kenon

Books), p. iv. 
35 Sarah Richardson (2013) The Political Worlds of Women: Gender and Politics in Nineteenth Century Britain (London \& New York: Routledge), p. 193.

36 Boas, 1931, pp. 77-94, on p. 83.

37 Kathryn Gleadle (2009) Borderline Citizens: Women, Gender and Political Culture in Britain 1815-1867 (Oxford: Oxford University Press), p. 1.

38 Charlotte Stopes, Add. 58454, ff. 2-52 Add. 58454, ff. 2-52 The Bacon-Shakespeare Question in Relation to Wine, Spirits and Beer, Wine, Spirit and Beer, February 1888, pp. 92-94.

39 Charlotte Stopes (1888) The Bacon/Shakespere Question (London : T. G. Johnson).

40 Charlotte Stopes (c.1920) Autobiographical Notes (Unpublished) Parts 1-4, Stopes-Roe Archive (hereafter S-R Archive), Birmingham, I, p. 86.

41 Aberdeen Journal, 20 September 1889, p. 4.

42 'The Root of the Matter: The Typical Woman's Reply to the Arguments of the Rational Dress Society', Punch, 22 February 1890, Press Clippings Album, S-R Archive.

43 Herald, 20 September 1889, Press Clippings Album, S-R Archive.

44 N. W. Senior Papers, National Library of Wales, Item E704.

45 Oscar Wilde to Charlotte Stopes, September 1888, BL MS, Add. 58454, f. 29.

46 Stopes papers, BL MS,

47 Stopes Papers, 21 Dec 1889, BL MS, Add. 58454, ff. 2-52, in f. 52.

48 Kathryn Prince (2008) Shakespeare in the Victorian Periodicals (New York: Routledge), p. 75.

49 Trodd (1998) quoted in Kathleen McLuskie (2013) 'Remembering Charlotte Stopes', in Gordon McMullan, Lena Cowan Orline \& Virginia Mason (Eds) Women Making Shakespeare: Text, Reception and Performance (London \& New York: Bloomsbury Arden Shakespeare), pp. 195-203, on p. 204.

50 Hall, Passionate Crusader, p. 18.

51 Dona Schneider \& David E. Lilienfeld (2011) Public Health: The Development of a Discipline (New Jersey: Rutgers University

Press), on pp. 4, 436.

52 Trodd quoted in McLuskie, 2013, p. 204.

53 Cassell \& Co. (1922) The Story of the House of Cassell 1848-1958 (London: Cassell \& Co. Ltd.).

54 Sue Thomas (1987) Indexes to Fiction in Cassell's Family Magazine - later Cassell's Magazine 1874-1910, Victorian Fiction

Research Guides, No. 12 at: http://www.victoriansecrets.co.uk/victorian-fiction-research-guides/cassells-family-magazine/

55 Arthur Fish, Oscar Wilde as Editor, Harper's Weekly (New York), October 4 1913, pp. 18-20, on p. 18.

56 Petra Dierke-Thrun (2012) Wilde's Editorship of the Woman's World: an overview, Literature Illuminations, No. 11 at:

https://litilluminations.wordpress.com/2012/11/

57 Charlotte Stopes to Marie Stopes, 25 July 1907, BL MS, Add. 58450, f. 55.

58 Chelmsford Chronicle, 25 Mar 1892, p. 6.

59 This was not connected with the community-based Women's Institutes, first set up in 1915 to foster regional development and support for the war effort during WWI.

60 The Women's Library, Women's Institute (Club), GB 106 9/15, 1897-1928 and GB 106 10/38, 1898-1927.

61 Charlotte Stopes (1908) The Sphere of 'Man' in Relation to that of 'Woman' in the Constitution (London: T Fisher Unwin).

62 Gwendolyn Murphy (1931) 'A Bibliographical List of the Works of Charlotte Stopes', in Essays by Divers Hands, Transactions of the Royal Society of Literature, 10 (London: Royal Society of Literature), pp. 95-107, on pp. 106-107.

63 Charlotte Stopes to Marie Stopes, 7 May 1905, BL MS, Add 58449, f. 240; Charlotte Stopes to Marie Stopes, 25 July 1907, BL

MS, Add. 58450, f. 55.

64 McLuskie, 2013, p. 200.

65 William Poel to Marie Stopes, 10 October 1928, S-R Archive. 
66 William Poel to Marie Stopes, 8 February 1929, S-R Archive. Poel established the Elizabethan Stage Society during the early 1880s.

67 Henry Woudhuysen (2013) ‘Some Women Editors of Shakespeare’, in McMullan, et. al., 2013, pp. 79-88, on p. 86.

68 Boas, 1931, p. 94.

69 In addition to those already cited, scholars who have revisited the life and work of Charlotte Stopes include: June Purvis \& Sandra Holton (Eds) (2000) Votes for Women (London: Routledge); Stephanie Green (2013) The Public Lives of Charlotte and Marie Stopes (London: Pickering \& Chatto).

70 Schoenbaum, 1970, pp. 460-461.

71 Charlotte Stopes (1894) British Freewomen: Their Historical Privilege (London: Swann Sonnenschein).

72 Sandra Holton (2000) 'The Making of Suffrage History', in J. Purvis \& Holton , 2000, p. 15.

73 Lesley Hall (1993) ‘Uniting Science and Sensibility: Maries Stopes and the Narratives of Marriage in the 1920s’, in Angela Ingram and Daphne Patai (Eds) Rediscovering Forgotten Radicals: British Women Writers 1889-1939 (Chapel Hill, University of North Carolina Press), p. 119. 